\title{
Pemberdayaan Peternak Melalui Pembuatan Biogas Sebagai Solusi Limbah Kotoran Ayam Ras Petelur
}

\author{
Arinda Trisna Widiansyah \& Anita Budi Rahayu \\ STKIP PGRI Nganjuk \\ Email: arindatrisna@stkipnganjuk.ac.id
}

\begin{abstract}
The business of laying hens is a business sector that provides a very large role in meeting the needs of animal protein and various industrial needs. This role cannot be replaced by vegetable protein sources. According to partners besides having great opportunities and benefits, laying hens also have problems, one of which is chicken manure. Mr. Hakim has tried several ways to remove the odor, such as raising the foundation of the cage so that it is not submerged by rainwater, spreading lime powder, and spraying EM4 liquid directly into chicken manure. But apparently not effective at reducing odors. One of the technical recommendations is the making of Biogas as an alternative energy source producing fuel substitutes for LPG gas, firewood, lighting and organic fertilizer. The results of community service activities to date have been the availability of biogas as an alternative energy producer for the use of biogas stoves and petromax lamps, as well as increased partner knowledge about biogas.
\end{abstract}

\begin{abstract}
Abstrak: Usaha sektor peternakan ayam ras petelur merupakan bidang usaha yang memberikan peranan sangat besar dalam pemenuhan kebutuhan protein hewani dan berbagai keperluan industri. Peranan ini tidak dapat digantikan oleh sumber protein nabati. Menurut mitra disamping memiliki peluang dan manfaat yang besar, peternakan ayam ras petelur juga memiliki permasalahan salah satunya yaitu kotoran ayam tersebut. Bapak Hakim sudah mencoba beberapa cara untuk menghilangkan bau tersebut seperti, meninggikan pondasi kandang agar tidak terendam air hujan, menebar serbuk kapur, serta menyemprot cairan EM4 langsung ke kotoran ayam. Namun ternyata belum efektif mengurangi bau. Salah satu rekomendasi teknis adalah pembuatan Biogas sebagai salah satu sumber energi alternatif penghasil bahan bakar pengganti gas LPG, kayu bakar, penerangan dan pupuk organik. Hasil kegiatan pengabdian sampai saat ini adalah tersedianya biogas sebagai penghasil energi alternatif untuk pemakaian kompor biogas dan lampu petromak, serta peningkatan pengetahuan mitra tentang biogas yang meningkat.
\end{abstract}

Kata Kunci: Biogas, Kotoran Ayam, Pemberdayaan. 


\section{PENDAHULUAN}

Ternak dan hasil produksinya merupakan sumber bahan pangan protein yang sangat penting untuk peningkatan kualitas sumber daya manusia Indonesia. Menurut databoks.katadata.co.id (2018) secara nasional perkembangan populasi berbagai jenis ternak menunjukkan peningkatan yang besar, salah satunya ternak ayam ras petelur. Saat ini telur ayam ras mampu memenuhi 65\% kebutuhan telur nasional sementara sisanya dipasok dari telur ayam kampung, itik dan puyuh. Selain itu, konsumsi telur ayam ras diprediksi mencapai 1,72 juta ton pada 2021. Atas dasar ini, pengembangan usaha peternakan ayam ras petelur diminati oleh masyarakat, tidak terkecuali masyarakat Trenggalek Jawa timur.

Usaha sektor peternakan ayam ras petelur merupakan bidang usaha yang memberikan peranan sangat besar dalam pemenuhan kebutuhan protein hewani dan berbagai keperluan industri. Protein yang terdapat pada telur memiliki fungsi penting dalam kehidupan sehari-hari manusia karena mengandung berbagai asam amino yang diperlukan untuk pertumbuhan dan kecerdasan manusia. Peranan ini tidak dapat di gantikan oleh sumber protein nabati (Purwaningsih, 2014).

Disamping memiliki peluang dan manfaat yang besar, peternakan ayam ras petelur juga memiliki banyak permasalahan. Menurut mitra yaitu Bapak Hakim, seorang peternak ayam ras petelur dari Dusun Salam Selatan RT 12 RW 05 Kelurahan Salamrejo Kecamatan Karangan Kabupaten Trenggalek, salah satu permasalahan yang dikeluhkan adalah kotoran ayam tersebut. Saat populasi ayamnya berkisar 50 ekor memang belum ada masalah. Namun dengan 700 lebih ekor ayam yang diternakkan sekarang, jumlah kotorannya pun tentu tidaklah sedikit.

Sementara itu di lokasi sepanjang jalan menuju peternakan, berderet rumah tetangga dengan selisih kurang dari 10 meter. Setiap angin berhembus dan hujan, bau kotoran ayam pun selalu terhirup oleh tetangga. Mitra sudah mencoba beberapa cara untuk menghilangkan bau tersebut seperti, meninggikan pondasi kandang agar tidak terendam air hujan, menebar serbuk kapur, serta menyemprot cairan EM4 langsung ke kotoran ayam. Namun ternyata belum efektif mengurangi bau. Oleh karena itu diperlukan rekomendasi teknis yang digunakan sebagai solusi permasalahan tersebut.

Salah satu rekomendasi teknis adalah pembuatan Biogas dengan berbahan baku kotoran ayam ras petelur. Selain itu hasil olahan biogas juga dapat dijadikan sebagai sumber energi alternatif. Menurut Sulistiyanto dkk (2016) gas dapat berasal dari berbagai macam limbah organik seperti sampah biomassa, kotoran manusia, kotoran hewan dapat dimanfaatkan menjadi energi melalui proses 
anaerobik digestion. Proses ini merupakan peluang besar untuk menghasilkan energi alternatif sehingga akan mengurangi dampak penggunaan bahan bakar fosil.

Melalui pengolahan atau pemanfaatan kotoran ayam ras petelur sebagai biogas, diharapkan dapat mengatasi permasalahan yang dihadapi mitra. Guna memproduksi gas yang dapat mencukupi kebutuhan dasar seperti memasak, penerangan, dan pupuk organik dibutuhkan setidaknya kotoran dari 170 ayam (Hartini, 2018). Selain itu hasil biogas ini diharapkan mampu menginspirasi masyarakat sekitar untuk memanfaatkan kotoran menjadi bahan bakar sebagai pengganti gas LPG, kayu bakar, penerangan dan pupuk organik.

\section{KAJIAN BIOGAS DAN METODE PEMBERDAYAAN}

Biogas adalah gas yang dihasilkan oleh bakteri apabila bahan organik mengalami proses fermentasi dalam reaktor (biodigester) dalam kondisi anaerob (tanpa udara) (Suyitno dkk, 2010). Biogas terdiri dari 50\% sampai 75\% metana $\left(\mathrm{CH}_{4}\right), 25 \%$ sampai $45 \%$ karbon dioksida $\left(\mathrm{CO}_{2}\right)$ dan sejumlah kecil gas lainnya. Biogas sekitar 20\% lebih ringan dibandingkan udara dan memiliki temperatur nyala antara $650^{\circ} \mathrm{C}$ (Rahayu Ade Sri dkk, 2015).

Tabel 1. Komposisi Biogas

\begin{tabular}{lcc}
\hline \hline Unsur & Rumus & Konsentrasi (\%Volume) \\
\hline \hline Metana & $\mathrm{CH} 4$ & $50-75$ \\
\hline Karbon dioksida & $\mathrm{CO}_{2}$ & $25-45$ \\
\hline Uap air & $\mathrm{H}_{2} \mathrm{O}$ & $2-7$ \\
\hline Oksigen & $\mathrm{O}_{2}$ & $<2$ \\
\hline Nitrogen & $\mathrm{N}_{2}$ & $<2$ \\
\hline Hidrogen Sulfida & $\mathrm{H}_{2} \mathrm{~S}$ & $<2$ \\
\hline Amonia & $\mathrm{NH}_{3}$ & $<1$ \\
\hline Hidrogen & $\mathrm{H}_{2}$ & $<1$
\end{tabular}

Sumber: nachwaschende-rohstoße.de dalam (Rahayu Ade Sri dkk, 2015).

Biogas sekitar 20\% lebih ringan dibandingkan udara dan memiliki temperatur nyala antara $650^{\circ} \mathrm{C}$ sampai $750^{\circ} \mathrm{C}$. Biogas merupakan gas yang tidak berbau dan tidak berwarna yang terbakar dengan bara biru yang serupa dengan liquefied petroleum gas (LPG). Biogas terbakar dengan efisiensi 60\% dalam tungku 
biogas konvensional, ia memiliki nilai kalori $20 \mathrm{MJ} / \mathrm{Nm}^{3}$. Volume biogas biasanya dinyatakan dalam satuan normal meter kubik $\left(\mathrm{Nm}^{3}\right)$ yaitu volume gas pada suhu $0^{\circ} \mathrm{C}$ dan tekanan atmosfer.

Proses produksi biogas memanfaatkan kemampuan alami mikroorganisme untuk menguraikan limbah organik. Komponen utama produksi biogas adalah metana. Gas ini dapat terbakar dengan oksigen. Energi yang dilepaskan dari pembakaran menjadikan biogas berpotensi sebagai bahan bakar. Biogas bisa digunakan untuk berbagai tujuan pemanasan, mulai dari memasak hingga sebagai bahan bakar untuk mesin di industri.

Produksi biogas dengan menggunakan limbah yang mudah ditemui dan dapat didegradasi secara biologis memiliki dua kelebihan utama. Secara ekonomis, baik biogas maupun limbah akhir yang dihasilkan dari proses degradasi dapat dimanfaatkan. Pada saat yang bersamaan, pemilik biogas mendapatkan cara yang aman dan cepat untuk memproses limbahnya sehingga menghindari dampak negatif terhadap lingkungan (Rahayu Ade Sri dkk, 2015).

Pemanfaatan biogas sebagai sumber energi pada industri kecil berbasis pengolahan hasil pertanian dapat memberikan multiple effect dan dapat menjadi penggerak dinamika pembangunan pedesaan. Selain itu, dapat juga dipergunakan untuk meningkatkan nilai tambah dengan cara pemberian green labelling pada produk-produk olahan yang diproses dengan menggunakan green energy. Di samping itu, usaha lain yang dapat bersinergi dengan kegiatan ini adalah peternakan cacing untuk pakan ikan/ungags, industri bata merah, industry kompor gas, dsb. Sehingga pengembangan teknologi biogas secara langsung maupun tidak langsung diharapkan dapat menciptakan lapangan kerja baru di pedesaan.

Pemanfaatan biogas dapat mengurangi emisi gas metana $\left(\mathrm{CH}_{4}\right)$ yang dihasilkan pada dekomposisi bahan organik yang diproduksi dari sektor pertanian dan peternakan. Penggunaan digester/reaktor kotoran ternak difermentasi menjadi gas metana (biogas). Gas metana termasuk gas yang menimbulkan efek rumah kaca yang menyebabkan terjadinya fenomena pemanasan global, karena gas metana memiliki dampak 21 kali lebih tinggi dibandingkan gas karbondioksida ( $\left.\mathrm{CO}_{2}\right)$ (Badan Litbang Pertanian, 2011).

Kandungan metana yang cukup tinggi dalam biogas dapat menggantikan peran LPG dan petrol (bensin). Tetapi dalam biogas terdapat kandungan lain selain metana yang perlu adanya proses pemurnian. Gas tersebut adalah gas $\mathrm{H}_{2} \mathrm{~S}$ yang dianggap sebagai pengotor dan bila ikut terbakar dan terbebas dengan udara dapat teroksidasi menjadi $\mathrm{SO}_{2}$ dan $\mathrm{SO} 3$ yang bersifat korosif dan bila teroksidasi lebih lanjut oleh $\mathrm{H}_{2} \mathrm{O}$ dapat memicu hujan asam. Selain $\mathrm{H} 2 \mathrm{~S}$ terdapat 
juga uap air dan $\mathrm{CO}_{2}$ yang tidak bermanfaat pada saat pembakaran (Suyitno, dkk. 2010).

Tabel 2. Pemanfaatan Biogas

\begin{tabular}{|c|c|c|}
\hline Pemanfaatan Biogas & Referensi & Hasil Pengukuran \\
\hline $\begin{array}{l}\text { 1. Lampu penerangan }(\mathrm{m} 3 / \\
\text { jam) }\end{array}$ & $\begin{array}{l}0,11-0,15 \text { (penerangan setara } \\
\text { dengan } 60 \text { watt lampu bohlam } \\
\cong 100 \text { candle power } \cong 620 \\
\text { lumen). } \\
\text { Tekanan: } 70-85 \mathrm{~mm}\end{array}$ & $\begin{array}{l}0,15-0,3 \\
\text { Tekanan }=30-60 \\
\mathrm{mmH}_{2} \mathrm{O}\end{array}$ \\
\hline 2. Kompor gas (m3/ jam) & $\begin{array}{l}\mathrm{H}_{2} \mathrm{O} \\
0,2-0,45 \\
0,3 \mathrm{~m} 3 / \text { orang/hari } \\
\text { Tekanan: } 75-90 \mathrm{mmH}_{2} \mathrm{O}\end{array}$ & $\begin{array}{l}0,2-0,4 \\
\text { Tekanan } \\
\mathrm{mmH}_{2} \mathrm{O}\end{array}$ \\
\hline $\begin{array}{l}\text { 3. Energi listrik } \\
\text { Algen gas generator ( } 700 \\
\text { W) Algen gas generator } \\
\text { (1.500 W) Modifikasi } \\
\text { diesel engine 6HP ( } 3000 \\
\text { W) }\end{array}$ & $\begin{array}{l}0,5 \mathrm{~m} 3 \text { biogas } / \mathrm{kwh} \\
0,35 \mathrm{~m} 3 \text { biogas } / \mathrm{kwh} \\
\text { perbandingan solar }: \text { biogas }= \\
10: 90\end{array}$ & $\begin{array}{l}0,55 \mathrm{~m} 3 \text { biogas } / \mathrm{kwh} \\
0,40 \mathrm{~m} 3 \text { biogas } / \mathrm{kwh} \\
100 \mathrm{ml} \text { solar, } \\
0,39 \mathrm{~m} 3 \text { biogas } / \mathrm{kwh}\end{array}$ \\
\hline
\end{tabular}
Sumber: Badan Litbang Pertanian (2011).

Di samping itu biogas dapat dimanfaatkan sebagai sumber energi pada kompor gas, lampu petromak, dan menggerakkan motor bakar (energi mekanis) dengan kebutuhan biogas seperti pada Tabel 2.

Tabel 3. Jumlah ternak yang diperlukan untuk produksi biogas skala keluarga

\begin{tabular}{|c|c|c|}
\hline Jenis Ternak & Jumlah (ekor) & Potensi Biogas \\
\hline Ruminansia besar & 2 & \multirow{5}{*}{$\begin{array}{l}\text { Menghasilkan } \\
\text { biogas setara } \\
\text { minyak tanah } \\
\text { 1,23 liter/hari }\end{array}$} \\
\hline Ruminansia kecil & 36 & \\
\hline Kuda & 3 & \\
\hline Babi & 15 & \\
\hline Unggas & 363 & \\
\hline
\end{tabular}

Sumber : Badan Litbang Pertanian, 2011.

Bahan baku yang dapat dibuat biogas adalah bahan organik. Beberapa daftar bahan organik yang dapat dibuat biogas adalah biomasa, kotoran manusia, kotoran hewan, urin, sampah kota yang berbentuk organik, dan sampah produk pertanian. Di Indonesia, jenis kotoran yang umum digunakan untuk menghasilkan biogas adalah kotoran sapi (Rahayu Ade Sri dkk, 2015). Jumlah ternak yang diperlukan untuk produksi biogas skala keluarga, adalah seperti pada Tabel 3. 
Badan Litbang Pertanian (2011) menyarankan beberapa hal yang perlu diperhatikan dalam pemeliharaan biogas. Diantaranya; a) Mengisi bahan baku (bahan organik) ke dalam reaktor sesuai kapasitas pengisian setiap hari; b) Menghindari bahan-bahan pengambat pertumbuhan bakteri (pestisida, desinfektan, air detergen/sabun, shampoo) masuk ke dalam reactor; c) Membersihkan peralatan (kompor, lampu, generator listrik), melakukan pemeriksaan jaringan pipa/selang gas dan bagian pengaman secara rutin dalam kurun waktu tertentu; dan d) Memanfaatkan lumpur keluaran dari instalasi biogas secara teratur. Sedangkan cara mengatasi masalah operasional pada biogas dapat dilihat pada Tabel 4.

Tabel 4. Masalah Operasional dan Cara Perbaikannya

\begin{tabular}{|c|c|c|}
\hline Kerusakan & Penyebab Kerusakan & Cara Perbaikan \\
\hline \multirow[t]{6}{*}{$\begin{array}{l}\text { 1. Masalah : Start } \\
\text { awal } \\
\text { a) Tekanan gas lemah }\end{array}$} & Bakteri sangat sedikit & $\begin{array}{l}\text { Kira-kira } 20 \text { kg slurry dari } \\
\text { instalasi biogas yang sudah } \\
\text { beroperasi diambil dan } \\
\text { dimasukkan ke dalam } \\
\text { digester tersebut. }\end{array}$ \\
\hline & Waktunya belum cukup lama & $\begin{array}{l}\text { Pada daerah dingin, pada } \\
\text { operasional pertama kali } \\
\text { perlu waktu } 3 \text { minggu } \\
\text { untuk mengisi penampung } \\
\text { gas. }\end{array}$ \\
\hline & $\begin{array}{l}\text { Mengisi digester sambil } \\
\text { menunggu terpenuhinya } \\
\text { penampung gas }\end{array}$ & $\begin{array}{l}\text { Ini kesalahan yang sering } \\
\text { terjadi. }\end{array}$ \\
\hline & $\begin{array}{l}\text { Tidak ada air di dalam } \\
\text { peralatan pengeluaran embun }\end{array}$ & $\begin{array}{l}\text { Jangan mengisi digester } \\
\text { dulu sampai gas metana } \\
\text { terbentuk. } \\
\text { Kira-kira } 0,25 \text { liter air } \\
\text { harus ditambahkan ke } \\
\text { dalam botol pencelup pipa. }\end{array}$ \\
\hline & $\begin{array}{l}\text { Kebocoran di penampung gas } \\
\text { atau pipa gas }\end{array}$ & Ini harus diperbaiki \\
\hline & $\begin{array}{l}\text { Keran gas atau keran } \\
\text { kondensasi terbuka }\end{array}$ & Harus segera ditutup \\
\hline $\begin{array}{l}\text { b) Gas pertama yang } \\
\text { dihasilkan tidak } \\
\text { terbakar }\end{array}$ & $\begin{array}{l}\text { Gas yang terbentuk bukan gas } \\
\text { metana }\end{array}$ & $\begin{array}{l}\text { Gas pertama yang } \\
\text { terbentuk jangan dibakar. } \\
\text { Ini mungkin banyak } \\
\text { campuran gas dan } \\
\text { mungkin bisa meledak. } \\
\text { Khususnya di daerah } \\
\text { bercuaca dingin, produksi } \\
\text { gas lambat, dan sering }\end{array}$ \\
\hline
\end{tabular}




\begin{tabular}{|c|c|c|}
\hline & & $\begin{array}{l}\text { kandungan } \mathrm{CO} 2 \text { nya } \\
\text { tinggi.Gas yang diproduksi } \\
\text { berikutnya dapat dibakar. }\end{array}$ \\
\hline & Udara di dalam pipa gas & $\begin{array}{l}\text { Udara hendaknya } \\
\text { dikeluarkan sampai yakin } \\
\text { keluar bau gas. }\end{array}$ \\
\hline \multirow[t]{5}{*}{$\begin{array}{l}\text { 2. Masalah Umum } \\
\text { Ketika salah satu } \\
\text { klep gas utama } \\
\text { dibuka, tekanan gas } \\
\text { turun drastis. }\end{array}$} & $\begin{array}{l}\text { Keran pengeluaran } \\
\text { pembuangan air terbuka }\end{array}$ & $\begin{array}{l}\text { Segera ditutup Kira-kira } \\
0,25 \text { liter } \\
\text { air harus ditambahkan } \\
\text { kedalam botol pencelup } \\
\text { pipa. }\end{array}$ \\
\hline & Keran gas/burner terbuka & \\
\hline & $\begin{array}{l}\text { Keran gas untuk lampu } \\
\text { terbuka }\end{array}$ & \\
\hline & $\begin{array}{l}\text { Tidak ada air di dalam peralan } \\
\text { pengeluaran air/syphon }\end{array}$ & \\
\hline & Bocor besar di jaringan pipa. & Harus segera diperbaiki \\
\hline \multirow[t]{4}{*}{$\begin{array}{l}\text { Tekanan gas naik } \\
\text { secara lambat. }\end{array}$} & Tekanan terlalu rendah. & $\begin{array}{l}\text { Produksi gas akan selalu } \\
\text { berkurang dalam } \\
\text { cuaca dingin }\end{array}$ \\
\hline & Buih tebal diatas slurry & $\begin{array}{l}\text { Penampung gas ditutup } \\
\text { rapat dan buih diambil dari } \\
\text { permukaan } \\
\text { c, d, jumlah yang tepat } \\
\text { harus ditambahkan } \\
\text { setiap hari. Ini akan } \\
\text { berjalan baik dengan } \\
\text { sendirinya setelah } \\
\text { beberapa minggu } \\
\end{array}$ \\
\hline & Pengisian terlalu banyak & $\begin{array}{l}\text { Pencampuran slurry } \\
\text { hendaknya jangan } \\
\text { berselang terlalu lama }\end{array}$ \\
\hline & Pengisian terlalu sedikit & \\
\hline \multirow[t]{4}{*}{ Gas tidak menyala } & $\begin{array}{l}\text { Pencampuran slurry berubah } \\
\text { banyak. }\end{array}$ & $\begin{array}{l}\text { Hanya memasukkan } \\
\text { campuran kotoran } \\
\text { ternak dan dan air setiap } \\
\text { hari. Setelah } 2 \\
\text { sampai } 6 \text { minggu keadaan } \\
\text { akan pulih. }\end{array}$ \\
\hline & $\begin{array}{l}\text { Memasukkan zat kimia, oli, } \\
\text { sabun, atau ditergen kedalam } \\
\text { slurry }\end{array}$ & $\begin{array}{l}\text { Kebocoran harus segera } \\
\text { diperbaiki } \\
\text { Slurry hendaknya dibuat } \\
\text { dengan kekentalan } \\
\text { yang tepat }\end{array}$ \\
\hline & Gas bocor & \\
\hline & $\begin{array}{l}\text { Campuran slurry terlalu } \\
\text { kental/terlalu encer }\end{array}$ & $\begin{array}{l}\text { Tidak boleh ada air ekstra } \\
\text { masuk kedalam }\end{array}$ \\
\hline
\end{tabular}




$\frac{\text { digester }}{\text { Sumber : Badan Litbang Pertanian (2011). }}$

Sumber : Badan Litbang Pertanian (2011).

\section{METODE}

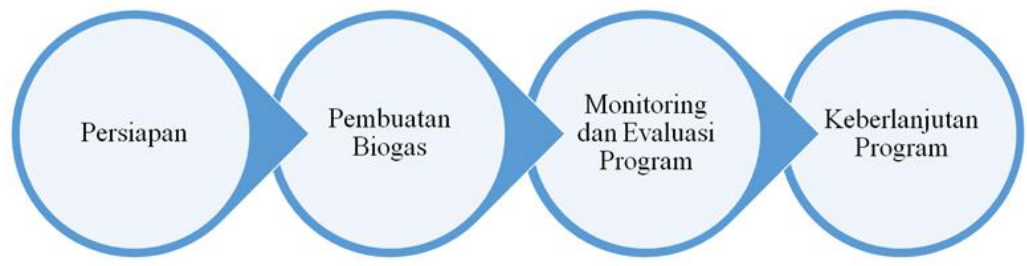

Gambar 1. Metode Pelaksaaan Program

Ada empat tahap yang dilalui dalam pelaksanaan pemberdayaan peternak dalam memanfaatkan limbah ternak untuk pembuatan biogas. Pertama, Tahap Persiapan yang meliputi dua kegiatan; Survei ke lokasi sasaran dan melakukan identifikasi permasalahan; dan Survei sarana dan prasarana mitra.

Kedua, Tahap Pembuatan Biogas. Tahap ini diawali dengan persiapan Lokasi Bangunan. Membangun instalasi biogas berada di lahan yang permukaan air tanahnya lebih dari 2 meter, hal ini dimaksudkan untuk menghindari adanya air tanah masuk ke ruang pembentukan biogas (digester/reaktor). Selain itu letak lokasi instalasi biogas tidak jauh dari kandang dan tempat pemanfaatan biogas. Langkah selanjutnya pembuatan Reaktor. Terapat tujuh hal yang perlu diperhatikan; a) Semua bahan yang digunakan untuk membuat konstruksi bangunan (batu bata, pasir, semen) harus bebas dari tanah dan kotoran lainnya; b) Menggali tanah sedalam kurang lebih 2 meter; c) Membuat campuran adonan cor (semen dan pasir) sedikit demi sedikit sesuai kebutuhan dan melakukan pengadukan di tempat yang bersih; d) Memilih batu bata yang utuh, atau untuk menghemat, pemasangan batu bata disusun miring; e) Memasang batu bata untuk dinding reaktor berbentuk kubah; f) Melapisi bagian dalam reaktor, terdiri dari lapisan pertama (2 pasir ayakan halus : 1 semen dan tebal lapisan $1 \mathrm{~cm}$. Agar lapisan semen pasir tersebut tidak retak, waktu pembuatan adonan dicampur dengan bahan anti retak untuk beton. Setelah itu mengecat dengan cat kapal secara merata sebagai lapisan kedua; dan g) Melapisi bagian luar dengan perbandingan semen dan pasir 1:3 setebal $1,5 \mathrm{~cm}$. langkah terakhir di tahap ini adalah Pembuatan Instalasi Saluran Biogas. Dua kegiatan yang dilakukan; Memasang saluran biogas antara reaktor dengan kompor, manometer, lampu pemasangan pada posisi miring, sehingga uap air yang mengembun akan jatuh di tempatnya; dan Memasang pipa PVC dengan benar-benar rapat. 
Ketiga, Tahap Monitoring dan Evaluasi Program. Monitoring dan evaluasi dilakukan pada mitra untuk mengetahui pemanfaatan hasil biogas untuk pemakaian kompor biogas, pemakaian lampu petromak dan pupuk organik. Sedangkan permasalahan yang muncul pada tahap ini, tetap dilakukan pendampingan untuk mencari solusi alternatif yang sesuai.

Keempat, Tahap Keberlanjutan Program. Setelah kegitaan ini selesai, jalinan kerjasama diharapkan tidak selesai begitu saja. Namun mitra tetap ada keberlanjutan kerjasama antara STKIP PGRI Nganjuk dengan STKIP PGRI Nganjuk misal konsultasi permasalahan operasional dan cara perbaikannya.

\section{HASIL DAN PEMBAHASAN}

Tiga tahap harus ditempuh oleh tim guna memastikan pemberdayaan peternak dalam memanfaatkan limbah untuk dibuat biogas berjalan dengan seksama. Pertama, Tahap Persiapan. Pada tahapan ini peneliti melakukan kegiatan survey biogas yang sudah jadi dan berfungsi di daerah Kecamatan Pule Kabupaten Trenggalek guna membandingkan teori pembuatan biogas dengan kondisi riil dilapangan. Berdasarkan hasil survey maka bangunan biogas terdiri dari 3 bangunan inti yaitu mixer, reaktor, dan outlet. Hal ini sesuai dengan teori bangunan biogas. Selanjutnya peneliti mensurvey lokasi mitra yang beralamat di Dusun Salam Selatan RT 12 RW 05 Kelurahan Salamrejo Kecamatan Karangan Kabupaten Trenggalek. Sarana dan prasarana yang di miliki oleh mitra sudah cukup memadai seperti adanya lahan yang bisa digunakan sebagai tempat reaktor biogas. Setelah itu melakukan koordinasi dengan tukang yang akan membantu dalam pembangunan biogas serta membuat kuisioner pengetahuan tentang biogas.

Tahap kedua, Tahap Pembuatan Biogas. Di tahap ini, ada lima komponen yang harus disiapkan dan diadakan oleh tim bersama dengan peternak selaku mitra pemberdayaan. Dimulai dengan pemilihan dan penyiapan . Lokasi Bangunan Reaktor Biogas. Pembangunan instalasi biogas berada di lahan yang permukaan air tanahnya lebih dari 2 meter untuk menghindari adanya air tanah masuk ke ruang pembentukan biogas (digester/reaktor). Selain itu letak lokasi instalasi biogas tidak jauh dari kandang dan tempat pemanfaatan biogas.

Dilanjutkan dengan Pembuatan Digester/Reaktor Biogas. Pada tahapan ini proses pembuatan reaktor biogas dengan cara menggali tanah sedalam kurang lebih 2 meter, memasang batu bata untuk dinding reaktor berbentuk melingkar, melapisi bagian luar dengan semen halus serta setelah kering di lanjut mengecat dengan cat pelapis anti bocor secara merata. Selanjutnya Pembuatan 
Instalasi Saluran Pipa Biogas. Pada tahapan ini memulai proses instalasi saluran pipa biogas dengan cara menggali tanah dan menimbun secukupnya sebagai jalan pipa dari reaktor ke manometer kompor, dan petromak.

Setelah beberapa komponen di atas siap, proses selanjutnya adalah Pemasangan Kompor, Petromak, dan Manometer Biogas. Pada tahapan ini memasang kompor biogas dengan menghubungkan dengan kompor biogas dengan kran pengeluaran gas serta menambah besar lubang masukkan gas ke dalam kompor. Petromak dipasang menggantung disekitar manometer. Indikator manometer biogas tidak menggunakan jarum melainkan menggunakan bahan cair karena tekanan yang dihasilkan rendah. Terakhir Tahap Pengisian Biogas. Pada tahapan ini menginput bahan baku berupa kotoran sapi dengan perbandingan 1 bagian kotoran dan 1 bagian air. Mengaduk campuran tersebut, kemudian mengalirkan ke dalam reaktor biogas sampai batas optimal lubang pengeluaran. Hal ini dilakukan karena proses fermentasi kotoran ayam yang lama sehingga diperlukan proses pengujian keberfungsian reaktor dan kebocoran pipa. Kemudian setelah gas pertama terbentuk dan tidak ditemukan kebocoran pipa maka pengisian kotoran ayam dilakukan satu minggu sekali.

Ketiga, Tahap Monitoring dan Evaluasi Program. Pada tahapan ini monitoring dan evaluasi dilakukan pada mitra untuk mengetahui pemanfaatan biogas. Reaktor biogas menghasilkan gas sehingga indikator manometer bergerak dan kompor serta petromak menyala. Sedangkan permasalahan yang muncul adalah api segera padam ketika kran pengeluaran gas diperbesar. Solusi permasalahan ini masih perlu analisis lebih lanjut. Selain untuk mengetahui pemanfaatan biogas, mitra juga diberikan angket kuisioner yang bertujuan untuk mengukur adanya peningkatan pengetahuan tentang biogas. Berdasarkan angket yang diperoleh adanya peningkatan pengetahuan mitra sebesar 21,7\%.

Hasil tersebut didapatkan dengan cara membandingkan hasil angket pada saat pre test sebesar 78,3\% (sebelum pembangunan biogas dan sharing tentang biogas) dengan post test sebesar 100\% (sesudah biogas terbangun dan dan sharing tentang biogas). Ketidaktahuan mitra terhadap materi biogas terlihat pada jawaban yang salah di no 12, 13, 16, 19, 20. Kekurangpahaman mitra terhadap biogas dikarenakan latar belakang mitra yang bukan lulusan jurusan sains serta kurangnya minat untuk mencari solusi terhadap limbah kotoran ternak ayamnya. Hal ini terlihat dari kotoran ayam yang hanya di tumpuk di bak pembuangan di samping kandang. Peningkatan pengetahuan biogas di dapatkan setelah proses pembangunan biogas dan sharing secara langsung pemahaman dari tim pelaksana pengabdian masyarakat. Selain itu pemahaman mitra bertambah setelah tim memberikan artikel dari jurnal sinartani Edisi 1-7 Juni 
2011 dengan judul biogas pembuatan konstruksi, operasional dan pemeliharaan instalasinya.

\section{KESIMPULAN}

Berdasarkan kegiatan pengabdian yang sudah dilakukan maka dapat disimpulkan tiga hal utama. Pertama, Tersedianya biogas sebagai penghasil energi alternatif untuk pemakaian kompor biogas. Kedua, Tersedianya biogas sebagai penghasil energi alternatif untuk pemakaian lampu petromak. Ketiga, Peningkatan pengetahuan mitra meningkat sebesar 21,7\%. Peternak sebagai mitra pemberdayaan bisa menjadikan biogas sebagai bahan baku untuk menopang kebutuhan energi di sekitarnya.

\section{DAFTAR PUSTAKA}

Anonim. 2018. Konsumsi Telur Ayam Ras Diprediksi Mencapai 1,72 Juta Ton Pada 2021. (Online) https://databoks.katadata.co.id/datapublish/2018/07/27/konsumsitelur-ayam-ras-diprediksi-mencapai-172-juta-ton-pada-2021 diakses 25 Agustus 2018

Badan Litbang Pertanian. 2011. Biogas Pembuatan Konstruksi, Operasional Dan Pemeliharaan Instalasinya. Jurnal Agroinovasi Edisi 1-7 (3408)

Hartini 2018. Erni. Reaktor Biogas. (Online) http://www.biru.or.id/index.php/digester/ diakses 25 Agustus 2018

Purwaningsih Dyah Listyo. 2014. Peternakan Ayam Ras Petelur Di Kota Singkawang. Jurnal online mahasiswa Arsitektur Universitas Tanjungpura. 2 (2), 78-88

Rahayu Ade Sri, dkk. 2015. Buku Panduan: Konversi POME Menjadi Biogas Pengembangan Proyek di Indonesia. Winrock International

Sulistiyanto dkk, 2016. Pemanfaatan Kotoran Sapi Sebagai Sumber Biogas Rumah Tangga di Kabupaten Pulang Pisau Provinsi Kalimantan Tengah. Jurnal Udayana Mengabdi, 15 (2), 150-158 
Suyitno, dkk. 2010. Teknologi Biogas Pembuatan, Operasional, Dan Pemanfaatan. Yogyakarta: Graha Ilmu 